ISSN : $2406-7415$

E-ISSN : 2655 - 9919

JURNAL AKUNTANSI DAN BISNIS KRISNADWIPAYANA

DOI: http://dx.doi.org/10.35137/jabk.v8i1.483

Volume 8 Nomor 1 (Januari - April) 2021

\title{
ANALISA PENERIMAAN DAN PENGELOLAAN DANA NASABAH PADA BANK JATENG CABANG KOORDINATOR MAGELANG
}

\author{
May Linda Nugraheni ${ }^{1)}$ \\ Fakultas Ekonomi Universitas Tidar \\ J1. Kapten Suparman No. 39, Tuguran, Potrobangsan, Kec. Magelang Utara, \\ Kota Magelang, Jawa Tengah \\ Handphone Penulis: 085739252232 ,e-mail: maylindanugraheni@gmail.com \\ Chaidir Iswanaji ${ }^{2)}$ \\ ${ }^{2}$ Fakultas Ekonomi Universitas Tidar \\ Jl. Kapten Suparman No. 39, Tuguran Potrobangsan, Kec. Magelang Utara, \\ Kota Magelang, Jawa Tengah \\ Handphone Penulis: 081392838228 ,e-mail: chais@untidar.ac.id
}

\begin{abstract}
The purpose of this study was to determine the Acceptance and Management of Customer Funds at Bank Jateng, Magelang Coordinator Branch. This type of research is qualitative, because it puts more emphasis on the process that is taken from actual events, after which it concluded. The source of this research comes from one of the informants or sources. The data in this research is the process of managing customer funds at Bank Jateng, Magelang Coordinator Branch. The data source of this research comes from an informant who was interviewed structurally. Based on the data analysis, it can be concluded that: (1) Receipt of customer funds at the Magelang Coordinator Branch Bank Jateng uses the accrual-based method. Funds received by the Magelang Coordinator Branch of the Central Java Bank can be in the form of demand deposits, savings deposits, and time deposits. These funds are collected from the community. (2) The management of customer funds at the Magelang Coordinating Bank Central Java shall use the cash-based method. Management of customer funds at Bank Jateng, the Coordinator of Magelang Branch in the form of loans, such as: Personal Loan (PLO), Small Business Credit (KUK), Multipurpose Credit, People's Business Credit (KUR), Kreditasalt Fur Wiederaufbau Credit (KFW), and additional business capital for family business activities.
\end{abstract}

Keywords: qualitative; cash; personal loan; credibility alt fur wiederaufbau.

\section{PENDAHULUAN}

Bank adalah lembaga keuangan yang
bertugas menghimpun dan
mengkontribusikan dana yang dihimpun
tersebut kepada masyarakat melalui kredit
guna meningkatkan taraf hidup masyarakat..
Sesuai dengan tugasnya bank memiliki dua
fungsi yakni fungsi utama dan fungsi
sampingan. Fungsi utama bank adalah
menghimpun dana dari masyarakat dan

kemudian menyalurkan dana tersebut kepada masyarakat. Sedangkan fungsi sampingan bank adalah sebagai pendukung kelancaran kegiatan pembayaran atau transaksi di masyarakat secara lokal, sebagai pendukung kelancaran kegiatan transaksi secara internasional, dan juga sebagai pencipta uang giral.

Dijelaskan dalam Undang-Undang no. 7 Tahun 1992, berdasarkan dari segi tugasnya bank dikategorikan menjadi tiga 
ISSN : $2406-7415$

E-ISSN : 2655 - 9919

JURNAL AKUNTANSI DAN BISNIS KRISNADWIPAYANA

DOI: http://dx.doi.org/10.35137/jabk.v8i1.483

jenis : Bank Sentral, Bank Umum, dan Bank Perkreditan Rakyat (BPR).

1. Bank Sentral, yaitu bank milik Negara yang bertanggungjawab untuk mengatur dan menjaga stabilitas harga atau nilai mata uang negara. Jadi bank sentral bertugas untuk menjaga tingkat inflasi agar terkendali untuk mengoptimalkan perekonomian dengan mengontrol keseimbangan jumlah uang dan barang. Dengan kata lain bank sentral bertugas juga mengatur kebijakan moneter negara, stabilitas sector perbankan, dan sistem finansial secara keseluruhan. Di Indonesia bank sentral dikenal sebagai Bank Indonesia.

2. Bank Umum, yaitu bank yang melaksanakan kegiatan perbankan secara secara konvensional atau berdasarkan prinsip syariah, yang dalam kegiatannya memberikan jasa dalam lalu lintas pembayaran. Seperti yang diketahui kegiatan perbankan termasuk mengumpulkan dana dari masyarakat, memberikan kredit atau pinjaman kepada masyarakat, lain dari itu juga termasuk pemindahan dana antar pihak, penyimpanan barang berharga dan jasa bank lainnya. Bank umum kini dikenal juga sebagai bank komersil.

3. Bank Perkreditan Rakyat (BPR), yaitu bank yang melaksanakan kegiatan perbankan secara konvensional atau berdasarkan prinsip syariah, tetapi kegiatannya tidak memberikan jasa dalam lalu lintas pembayaran. Jadi kegiatannya jauh lebih sempit dibandingkan bank umum. Tugas BPR hanya sebatas pada penghimpunan dana dalam bentuk tabungan atau deposito dan penyaluran dana dalam bentuk
Volume 8 Nomor 1 (Januari - April) 2021

kredit investasi, kredit modal kerja atau kredit perdagangan.

Lembaga ini bertindak sebagai perantara diantara pihak yang memiliki uang atau dana lebih dengan pihak yang membutuhkan uang atau dana dan juga pihak yang melancarkan arus pelunasan. Bank dalam proses penyusunan laporan keuangannya menggunakan akuntansi perbankan. Dimana akuntansi perbankan tersebut wajib menyesuaikan sesuai prinsip akuntansi yang berterima umum.

Setidaknya terdapat ketidaksamaan antara akuntansi perbankan dengan akuntansi perusahasan. Ketidaksamaan yang mendasar terletak pada proses pencatatan arus kasnya, dimana uang yang masuk dengan uang yang keluar pada akuntansi perbankan berbeda dengan akuntansi perusahaan pada umumnya, oleh karena itu dibutuhkan penyesuaian pada akuntansi biayanya.

Ketidaksamaan lainnya dilihat dari kekayaan bank, modal, serta kewajiban bank. Kekayaan bank terdiri atas penyediaan dana guna mendapatkan penghasilan dalam beberapa bentuk seperti transaksi derivative, surat berharga, kredit, dan lain-lain. adalah dana pinjaman, dana masyarakat, serta dana lainnya. Sementara modal bank sendiri berasal dari pemilik bank yang menginvestasikan dananya untuk kegiatan operasional dan regulasi bank. Sedangkan kewajiban bank berfungsi untuk mengatasi masalah seperti kesulitan mencari modal tambahan dari pihak pertama. Kewajiban bank ini dapat diperoleh melalui kredit likuiditas, pinjaman antar bank, fasilitas diskonto, dan lain sebagainya.

Laporan keuangan bank bertujuan sebagai media penyedia informasi terkait posisi dan kinerja keuangan suatu bank yang 
ISSN : $2406-7415$

E-ISSN : 2655 - 9919

JURNAL AKUNTANSI DAN BISNIS KRISNADWIPAYANA

DOI: http://dx.doi.org/10.35137/jabk.v8i1.483

bermanfaat untuk mengambil sebuah keputusan. Tujuan lainnya dari laporan keuangan bank yaitu sebagai media komunikasi antara pihak internal dengan pihak eksternal terkait kondisi keuangan bank tersebut.

Bank Jateng Cabang Koordinator Magelang selama ini dalam melaksanakan proses pelaporan keuangannya sesuai dengan metode pelaporan keuangan sesuai aturan dari induk Bank Jateng Cabang Koordinator Magelang yang letaknya berada di Semarang, Jawa Tengah. Metode pencatatan yang digunakan adalah metode pencatatan berbasis akrual dan metode pencatatan berbasis kas, dimana dua metode pencatatan ini merupakan ketetapan dari induk Bank Jateng Cabang Koordinator Magelang. Pencatatan berbasis akrual adalah sebuah metode pencatatan yang akan dicatat dan diakui ketika transaksi sedang terjadi. Sedangkan pencatatan berbasis kas merupakan metode pencatatan dimana pendapatan akan dicatat pada saat kas dimasukkan, dan biaya akan dicatat pada saat kas dikeluarkan. Namun, porsi pemakaian antara kedua metode tersebut tetap banyak menggunakan metode berbasis akrual daripada metode berbasis kas. Keberadaan Bank Jateng Cabang Koordinator Magelang di wilayah Magelang yakni untuk memudahkan dalam menyalurkan pinjaman dan kredit lunak serta layanan perbankan lainnya bagi nasabah.

Penelitian sebelumnya yang telah dilakukan oleh Adiguna Prasetya Utama, 2015 mengenai Analisis Akuntansi Penerimaan dan Pengelolaan Dana Pada PT Bank Rakyat Indonesia Unit Pabelan Kartasura. Hasil dari penelitian ini menunjukkan bahwa akuntansi penerimaan
Volume 8 Nomor 1 (Januari - April) 2021

dana oleh BRI unit Pabelan, Kartasura menggunakan sistem akuntansi berbasis akrual, dimana dana yang dihimpun dari masyarakat yang dapat diterima di BRI unit Pabelan antara lain tabungan dalam bentuk layanan tabungan simpedes, tabungan simaskot, dan tabungan BriTama. Sedangkan akuntansi penerimaan dana oleh unit Pabelan, untuk pengelolaan dana bank BRI unit Pabelan terutama penyalur kredit kepada masyarakat. Kredit yang dapat dilayani berupa kredit investasi, kredit modal kerja, kredit profesi maupun penyaluran kredit dari Kupedes dan KUR.

Uraian latar belakang diatas, maka peneliti merumuskan suatu masalah yakni: Bagaimana Proses Penerimaan dan Pengelolaan Dana Nasabah pada Bank Jateng Cabang Koordinator Magelang. Tujuan penelitian ini untuk mengetahui proses Penerimaan dan Pengelolaan Dana Nasabah pada Bank Jateng Cabang Koordinator Magelang. Dana adalah sejumlah uang atau sumber lain yang disishkan untuk tujuan penyelenggaraan kegiatan tertentu atau mendapatkan objek tertentu yang sesuai dengan ketentuan dan pembatasan khusus dan yang disusun sebagai satuan keuangan dan pembukuan tersendiri (Drs Kustadi Arinta). Secara umum, dana adalah himpunan dari uang dalam jumlah tertentu, baik dalam bentuk tunai maupun nontunai. Dalam arti luas, dana juga bisa berarti modal usaha dalam menjalankan sebuah bisnis. Didalam perbankan, dana dihimpun dari masyarakat kemudian bank menyalurkan kembali dana tersebut kepada masyarakat untuk kegiatan ekonomi dan proyek pembangunan.

Manfaat dari penelitian ini adalah sebagai wujud partisipasi peneliti dalam perkembangan ilmu pengetahuan, terutama 
ISSN : $2406-7415$

E-ISSN : 2655 - 9919

JURNAL AKUNTANSI DAN BISNIS KRISNADWIPAYANA

DOI: http://dx.doi.org/10.35137/jabk.v8i1.483

dibidang akuntansi perbankan tentang penerimaan dan pengelolaan dana nasabah. Oleh karena itu penelitian ini lebih mengarah ke teori kemudian disusul dengan praktek langsung di lapangan. Di dunia perbankan, untuk penerimaan dana, sumber utamanya berasal dari giro, tabungan masyarakat dan lain-lain. Sedangkan pengelolaannya lebih berfokus pada penggunaan dan penyaluran serta pemanfaatan dana tersebut kepada masyarakat yang berbentuk kredit.

\section{LANDASAN TEORI}

\section{Teori Keagenan (Agency Theory)}

Menurut Jansen dan Meckling (1976), agency theory adalah masalah yang berkaitan dengan perbedaan kepentingan dalam hal pengambilan keputusan antara agen dan principal. Hubungan kontraktual antara principal atau pemilik perusahaan dengan agency atau manajemen perusahaan sebagai pengelola dimana terjadi pendelegasian wewenang dari pemilik kepada pengelola, inilah yang dibahas dalam teori ini. Masalah dalam keagenan ini disebabkan oleh adanya asymmetric information antara pemilik dan pengelola.

Demikian juga dalam entitas perbankan, dalam hal ini PT Bank Pembangunan Daerah Jawa Tengah Cabang Koordinator Magelang harus membuat laporan keuangan. Dimana fungsi laporan keuangan ini bertujuan sebagai bentuk pertanggungjawaban atas kegiatan-kegiatan pelayanan atau jasa yang diberikan.

\section{METODE PENELITIAN}

Jenis penelitian ini adalah penelitian kualitatif. Penelitian kualitatif adalah sebuah
Volume 8 Nomor 1 (Januari - April) 2021

penelitian yang berbentuk deskriptif dan lebih ditekankan pada analisisnya. Proses dan makna (perspektif subjek) lebih ditonjolkan dalam penelitian kualitatif. Agar peneliti fokus di lapangan sehingga hasil penelitian yang didapat sesuai dengan fakta di lapangan maka penelitian ini berlandasakan teori. Manfaat lainnya dari adanya landasan teori yaitu dapat menggambarkan latar belakang penelitian sehingga hasil penelitiannya sesuai dengan apa yang diharapkan oleh peneliti. Subjek penelitian ini adalah seorang informan atau narasumber. Informan atau narasumber adalah seseorang yang memberikan atau mengetahui secara jelas tentang suatu informasi. Untuk mendapatkan informasi tersebut, penelitian ini menggunakan teknik observasi dan wawancara.

\section{HASIL PENELITIAN DAN PEMBAHASAN}

\section{Sejarah Singkat Bank Jateng Cabang Koordinator Magelang}

Bank Jateng Cabang Koordinator Magelang didirikan tahun 1975 bertempat di Karesidenan Magelang. Kemudian relokasi sampai sekarang di Jalan Aloon-Aloon Selatan No. 11 Magelang. Pendirian Bank Jateng Cabang Koordinator Magelang merupakan langkah strategis yang dilakukan oleh Direksi dalam mengampu dan mengkoordinasikan 6 (enam) Kantor Cabang seWilayah Kedu yaitu : Kantor Cabang Purworejo, Kantor Cabang Temanggung, Kantor Cabang Magelang, Kantor Cabang Kebumen, Kantor Cabang Wonosobo, dan Kantor Cabang Yogyakarta, serta menjadi salah satu sarana dan upaya PT Bank Pembangunan Daerah 
ISSN : $2406-7415$

E-ISSN : $2655-9919$

JURNAL AKUNTANSI DAN BISNIS KRISNADWIPAYANA

DOI: http://dx.doi.org/10.35137/jabk.v8i1.483

Jawa Tengah sebagai Bank Umum dengan usaha penghimpunan dana masyarakat, penyaluran kredit, serta melakukan kegiatan di bidang jasa sehingga pada akhirnya dapat memberikan kontribusi yang memadai dalam pembangunan, menjadi kebanggan masyarakat, dan menjadi suatu Lembaga Keuangan yang terpercaya oleh masyarakat, serta mampu menunjang pembangunan daerah dengan tujuan meningkatkan kesejahteraan masyarakat.

Bank Jateng Cabang Koordinator Magelang sendiri memiliki wilayah kerja meliputi Kota dan Kabupaten Magelang yang mempunyai layanan sampai keseluruh kota dan kabupaten Magelang baik berupa layanan Kantor Cabang Pembantu, Kantor Kas, Payment Point, Mobil Keliling, dan ATM yang melayani kebutuhan transaksi keuangan masyarakat di wilayah kerja Bank Jateng Cabang Koordinator Magelang. Kebijakan direksi menyatakan bahwa setiap kecamatan harus dapat dilayani oleh Bank Jateng melalui setiap instrument layanan yang tersebar di wilayah kerja Bank Jateng Cabang Koordinator Magelang.

\section{Deskripsi Data Hasil Penelitian dan Pembahasan}

\section{Penerimaan Dana Nasabah Bank} Jateng Koordinator Cabang Magelang Sumber dana bank adalah usaha bank dalam menghimpun dana untuk membiayai operasinya. Sumber-sumber dana dalam bank dibagi menjadi tiga, yaitu: (1) Dana yang bersumber dari bank itu sendiri, artinya sumber dana berasal dari modal sendiri. Maksud dari modal sendiri adalah modal setoran dari para pemegang saham. (2) Dana yang berasal dari masyarakat luas, artinya sumber dana ini merupakan sumber dana
Volume 8 Nomor 1 (Januari - April) 2021

terpenting bagi kegiatan operasi bank dan merupakan ukuran keberhasilan sebuah bank jika mampu membiayai operasinya dari sumber dana ini. Adapun bentuk sumber dana ini yaitu berbentuk simpanan giro, simpanan tabungan, dan juga simpana deposito. (3) Dana yang bersumber dari lembaga lainnya, merupakan sumber dana tambahan jika bank mengalami kesulitan dalam pencarian sumber dana pertama dan kedua. Pencarian sumber dana ini relative lebih mahaldan sifatnya hanya sementara waktu saja.

Sumber dana yang bersumber dari masyarakat merupakan sumber dana yang berbentuk simpanan giro (demand deposito), simpanan tabungan (saving deposit), simpanan deposito (time deposit). Adapun beberapa produk Bank Jateng Koordinator Cabang Magelang yang peneliti ketahui, yaitu sebagai berikut : Tabungan, Giro, Deposito, Sertifikat Deposito, dan DPLK (Dana Pensiun Lembaga Keuangan). Selain produk diatas, ada beberapa pelayanan yang ditawarkan oleh Bank Jateng Cabang Koordinator Magelang, diantaranya : Kliring, Transfer, Inkaso, Bank Garansi, BPD Card, Real Time Gross Settlement (RTGS), danPembayaran PBB.

\section{Pengelolaan Dana Nasabah Bank Jateng Cabang Koordinator Magelang}

Pengelolaan dana dalam bank kepada masyarakat sebagian besar berbentuk kredit. Dimana peranan kredit yaitu untuk menambah modal masyarakat yang membutuhkan dana dalam rangka memperkuat struktur permodalannya. 
ISSN : $2406-7415$

E-ISSN : 2655 - 9919

JURNAL AKUNTANSI DAN BISNIS KRISNADWIPAYANA

DOI: http://dx.doi.org/10.35137/jabk.v8i1.483

Bank Jateng Cabang Koordinator Magelang memiliki beberapa produk kredit seperti : Kredit Personal Loan (PLO), Kredit Usaha Kecil (KUK), Kredit Multiguna, Kredit Usaha Rakyat, Kredit Kreditasalt fur Wiederaufbau (KFW), dan tambahan modal usaha untuk kegiatan usaha keluarga. Berbagai produk kredit ini dihadirkan oleh Bank Jateng Cabang Koordinator Magelang dengan bunga yang kompetitif sehingga masyarakat akan merasa terbantu dengan produk kredit yang ditawarkan oleh Bank Jateng Cabang Koordinator Magelang.

\section{Temuan Studi Yang Dihubungkan Dengan Kajian Teori}

1. Penerimaan Dana Nasabah

Penelitian yang dihasilkan pada Bank Jateng Cabang Koordinator Magelang dalam penerimaan dana nasabah menggunakan metode berbasis akrual. Metode ini merupakan sistem akuntansi perbankan yang diterapkan pada penerimaan dana terutama diperoleh dari masyarakat yang berbentuk simpanan giro, simpanan tabungan, dan simpanan deposito.

2. Pengelolaan Dana Nasabah

Pendapatan vital sebuah bank adalah kredit dari nasabah. Karena itu, pola pencatatannya harus serasi antara suku bunga yang diberikan dengan masa angsuran. Artinya semakin lama waktu kredit, suku bunga semakin besar, begitu juga sebaliknya. Dalam akuntansi, istilah ini dikenal dengan Ceteris Paribus.

Penghambat pada sistem ini salah satunya adalah jika terjadi banyak kredit macet dan tidak dibayar. Jika hal ini dibiarkan dalam skala yang besar dan jangka waktu yang lama, maka bank
Volume 8 Nomor 1 (Januari - April) 2021

akan mengalami kerugian yang luar biasa. Sehingga untuk mencegah keracunan tersebut, maka dmenggunakan metode pencatatan berbasis cash. Yang artinya, dimana uang angsuran yang masuk dicatat sebagai tagihan bukan pendapatan. Dengan menggunakan metode ini maka akan ketahuan mana kredit yang lancer dan mana kredit yang macet. Sehingga Bank Jateng Cabang Koordinator Magelang juga menggunakan metode berbasis kas, meskipun porsinya tidak sebanyak metode berbasis akrual.

\section{KESIMPULAN DAN SARAN}

\section{Kesimpulan}

Berdasarkan penelitian dan hasil pembahasan dapat disimpulkan :

1. Bank Jateng Cabang Koordinator Magelang merupakan Bank Pembangunan Daerah milik Pemerintah Daerah Provinsi Jawa Tengah. Bank Jateng Cabang Koordinator sendiri wilayah kerja meliputi Kota Magelang dan Kabupaten Magelang yang mempunyai layanan sampai keseluruh Kota Magelang dan Kabupaten Magelang baik berupa layanan Kantor Cabang Pembantu, Kantor Kas, Payment Point, Mobil Keliling dan ATM yang melayani kebutuhan transaksi keuangan masyarakat di wilayah kerja Bank Jateng Cabang Koordinator Magelang. Kebijakan direksi menyatakan bahwa setiap kecamatan, baik yang berada 
ISSN : $2406-7415$

E-ISSN : 2655 - 9919

JURNAL AKUNTANSI DAN BISNIS KRISNADWIPAYANA

DOI: http://dx.doi.org/10.35137/jabk.v8i1.483

dilingkup kota maupun kabupaten harus dapat dilayani oleh Bank Jateng melalui instrument layanan yang tersebar di wilayah kerja Bank Jateng Cabang Koordinator Magelang

2. Penerimaan dana nasabah pada Bank Jateng Cabang Koordinator Magelang menggunakan metode berbasis akrual. Dimana dana yang diterima oleh Bank Jateng Cabang Koordinator Magelang dapat berupa simpanan giro, simpanan tabungan, dan simpanan deposito. Dana tersebut dihimpun dari masyarakat.

3. Pengelolaan dana nasabah pada Bank Jateng Cabang Koordinator Magelang menggunakan metode berbasis cash. Pengelolaan dana nasabah pada Bank Jateng Cabang Koordinator Magelang berbentuk kredit, seperti : Kredit Personal Loan (PLO), Kredit Usaha Kecil (KUK), Kredit Multiguna, Kredit Usaha Rakyat (KUR), Kredit Kreditasalt Fur Wiederaufbau (KFW), dan tambahan mrodal usaha untuk kegiatan usaha keluarga.

\section{Saran}

1. Sebaiknya membuat program-program yang menarik terkait simpanan giro. Supaya minat calon nasabah membuat simpanan giro edi Bank Jateng Cabang Koordinator Magelang menjadi tinggi. Dengan demikian, besar kesempatan Bank Jateng Cabang Koordinator Magelang untuk membuat uang giral.

2. Produk tabungan yang dimiliki Bank Jateng Cabang Koordinator Magelang harus mampu bersaing dengan prodmbuk tabungan bank-bank lain
Volume 8 Nomor 1 (Januari - April) 2021

yang berada di magelang, sehingga sumber dana yang dihasilkan dapat dipakai untuk menunjang biaya operasional Bank Jateng Cabang Koordinator Magelang dalam memperoleh keuntungan.

3. Rajin mensosialisasikan pentingnya berinvestasi dalam bentuk deposito kepada masyarakat.

\section{DAFTAR PUSTAKA}

Taswan. 2013. Akuntansi Perbankan Edisi III. Yogyakarta: UPP STIM YKPN.

Chandrarin Grahita. 2018. Metode Riset Akuntansi. Jakarta: Salemba Empat.

Pedoman Akuntansi Perbankan Indonesia. 2008. Jakarta: Bank Indonesia.

Dikutip 17 April 2020 dari Sejarah Singkat Bank Jateng Cabang Koordinator Magelang www.bankjateng.co.id/branch_atm.p $\underline{\mathrm{hp}}$

Dikutip 20 April 2020 dari Pengertian Akuntansi Perbankan, Prinsip, Dan Manfaatnya https://cpssoft.com/blog/akuntansi/pe ngertian-akuntansi-perbankan/

Dikutip 2 Mei 2020 dari Pengertian Akuntansi Perbankan dan PrinsipPrinsip Dasar Yang Perlu Anda Ketahui: https://www.jurnal.id/id/blog/2018pengertian-akuntansi-perbankan-danprinsip-prinsip-dasar-yang-perluanda-ketahui. 
ISSN : $2406-7415$

E-ISSN : 2655 - 9919

JURNAL AKUNTANSI DAN BISNIS KRISNADWIPAYANA

DOI: http://dx.doi.org/10.35137/jabk.v8i1.483

Volume 8 Nomor 1 (Januari - April) 2021

http://eprints.ums.ac.id/32680/18/NA

SKAH\%20PUBLIKASI.pdf 
ISSN : $2406-7415$

E-ISSN : 2655 - 9919

JURNAL AKUNTANSI DAN BISNIS KRISNADWIPAYANA

DOI: http://dx.doi.org/10.35137/jabk.v8i1.483

Volume 8 Nomor 1 (Januari - April) 2021 